\title{
Danuta Glondys, Małgorzata Bednarczyk: Komunikacja międzykulturowa albo lepiej nie wychodź z domu. Kraków 2020, Wydawnictwo Uniwersytetu Jagiellońskiego, ss. 166 ISBN: 978-83-2334-898-6
}

Kursy z zakresu komunikacji międzykulturowej są prowadzone na polskich uczelniach od kilku dekad. Widnieją w programach studiów rozmaitych kierunków: filologii, dziennikarstwa, zarządzania, stosunków międzynarodowych i wielu innych, a uniwersyteckie biura karier nierzadko oferują studentom szkolenia właśnie na temat efektywnej współpracy w środowisku zróżnicowanym kulturowo. Wzrost zainteresowania tą tematyką przez długi czas nie znajdował swojego wyraźnego odzwierciedlenia na polskim rynku wydawniczym. Tytułów nawiązujących do kontekstu międzykulturowego pojawiło się rzecz jasna wiele, jednak na ogół były to pozycje odnoszące się do konkretnej specjalizacji, w tym przede wszystkim do kontekstu biznesowego. Tym bardziej z ogromnym zaciekawieniem sięgnęłam po monografię zatytułowaną Komunikacja międzykulturowa albo lepiej nie wychodź z domu autorstwa Danuty Glondys i Małgorzaty Bednarczyk, która została wydana w 2020 roku nakładem Wydawnictwa Uniwersytetu Jagiellońskiego. Liczyłam na to, że jest to opracowanie traktujące komunikację międzykulturową jako odrębną dyscyplinę oraz będzie mogło posłużyć jako podręcznik podczas zajęć z tego zakresu.

Recenzowana publikacja zwróciła moją uwagę także ze względu na tytuł, którego drugi człon może wprowadzać w pewne skonfundowanie. Czy mamy do czynienia z książką o charakterze akademickim, popularyzatorskim czy może poradnikowym? Czytelnik szybko przekonuje się jednak, że taki zabieg był zastosowany w tytule celowo, a Komunikacja międzykulturowa albo lepiej nie wychodź z domu to opracowanie łączące wszystkie trzy wymienione wyżej podejścia, co stanowi jego niewątpliwy atut. Przyjęta przez Danutę Glondys i Małgorzatę Bednarczyk perspektywa z pewnością wynika z ich 
różnorodnych doświadczeń międzykulturowych - obie autorki są wykładowcami na polskich i zagranicznych uczelniach, współpracują z sektorem publicznym i prywatnym właśnie w obszarze międzykulturowym, a także pasjonują się dalekimi podróżami, przez co można je z przekonaniem uznać zarówno za teoretyków, jaki i praktyków komunikacji międzykulturowej. Nieustanne przenikanie się teorii z praktyką jest też wyraźnie dostrzegalne $\mathrm{w}$ recenzowanym wydawnictwie.

Książka liczy 166 stron i zawiera 11 rozdziałów poprzedzonych Wstępem oraz zwieńczonych Zakończeniem. Można powiedzieć, że ma ona strukturę lejkową - autorki najpierw zarysowują ramy problematyki, którą zamierzają się zająć, by następnie przechodzić do coraz węższych i specjalistycznych tematów. Pierwszy rozdział poświęcony został wprowadzeniu do komunikacji międzykulturowej jako intensywnie rozwijającej się dziedziny nauki, której immanentną cechą jest funkcjonowanie na pograniczu różnych dyscyplin. Czytelnik od pierwszych stron dostrzega także, że obok wywodu o charakterze teoretyczno-naukowym występują wyróżnione graficznie treści, które można by określić jako „ciekawostki”. Nie mają one jednak jedynie na celu zaintrygowania odbiorcy, lecz stanowią uzasadnione i wartościowe uzupełnienie zagadnień omawianych w tekście głównym. Te oznaczone symbolem kuli ziemskiej odnoszą się na ogół do różnego rodzaju międzykulturowych anegdot, również tych osobistych, odwołujących się do doświadczeń zawodowych i podróżniczych autorek. Z kolei fragmenty oznaczone symbolem książki interpretuję jako zachętę do sięgnięcia po przytaczane przez autorki pozycje naukowe. Takie elementy pojawiają się w każdym rozdziale i bez wątpienia stanowią element znacznie urozmaicający lekturę oraz znakomicie ilustrujący omawiane koncepcje i zagadnienia.

Kolejne dwa rozdziały odnoszą się kolejno do dwóch istotnych dla badań nad komunikacją międzykulturową dyscyplin: historii i geografii. W pierwszym z nich znajdujemy odniesienie do teorii nierówności oraz omówienie takich kluczowych dla namysłu nad relacjami interkulturowymi pojęć, jak m.in. etnocentryzm, europocentryzm, orientalizm i rasizm. W drugim natomiast przedstawiono sposób ujmowania relacji międzykulturowych w perspektywie geografii kulturowej, omówiono ponadto pojęcie „trzeciej kultury” Freda Casmira. Obie te kwestie są, jak się wydaje, niewystarczająco często poruszane przez polskich autorów.

Koncepcje kultury i komunikacji, Tożsamość kulturowa $i$ Wielokulturowość Europy - tak zatytułowane kolejne rozdziały pozwalają czytelnikowi zapoznać się z fundamentalnymi dla komunikacji międzykulturowej pojęciami. 
W każdym z nich zauważalna jest konsekwentna realizacja sformułowanego we Wstępie zamierzenia, by komunikację międzykulturową przedstawić w sposób wysoce interdyscyplinarny - autorki nawiązują m.in. do językoznawstwa, kulturoznawstwa i religioznawstwa, dzięki czemu udaje im się udowodnić tezę o tym, że wiedza z zakresu komunikacji międzykulturowej może się przydać przedstawicielom rozmaitych dyscyplin. Z uzasadnionych przyczyn niektóre ustępy mają bardzo skondensowaną formę, jak na przykład w przypadku omówienia założeń trzech największych religii. Jasne jest, że takie informacje mają stanowić pewnego rodzaju egzemplifikację zróżnicowania (np. religijnego) świata i stanowić przyczynek do zgłębiania prezentowanej problematyki. Wątpliwości może jednak budzić fakt, że fragmenty dotyczące największych światowych religii, a także wiele innych w recenzowanej publikacji zostały opracowane na podstawie Wikipedii. Źródło to bez wątpienia jest obecnie znacznie bardziej wiarygodne niż jeszcze kilka lat temu, wydaje się jednak, że wymagającego czytelnika ten powtarzający się zapis w przypisach może nieco razić.

Rozdziały 7, 8 i 9 dotyczą pokrewnych tematów i zawierają omówienie trzech - można by rzec: klasycznych dla komunikacji międzykulturowej koncepcji typologii kultur. Autorki odnoszą się kolejno do propozycji Geerta Hofstedego, Richarda Gestelanda oraz Edwarda T. Halla. Niewątpliwym atutem tych rozdziałów jest umiejętne ilustrowanie omawianych sposobów klasyfikacji kultur za pomocą różnorodnych i barwnych przykładów stanowiących pewnego rodzaju pomost między teorią a praktyką. Należy jednak zauważyć, że koncepcje te są dosyć stare i wielokrotnie były przedmiotem krytyki (w szczególności dokonania Hofstedego, które bywają określane jako nienaukowe i sprzeczne z podstawowymi wymogami metodologicznymi). Bez wątpienia ich znajomość może poszerzyć horyzonty czytelnika i uwrażliwić go na to, jak szerokie jest spektrum różnic kulturowych. Szkoda jedynie, że autorki nie wspomniały o słabościach omawianego podejścia oraz kontrowersjach, które może wzbudzać.

Dwa ostatnie rozdziały poświęcono zagadnieniom bardziej specjalistycznym, mającym silny związek z praktyką. W tym zatytułowanym Kultury negocjacji przeczytać można najpierw o sztuce negocjacji w ujęciu ogólnym, a następnie zapoznać się ze specyfiką zachowań komunikacyjnych tego rodzaju w ujęciu międzynarodowym. Podobnie w przypadku kolejnego rozdziału, dotyczącego dyplomacji - czytelnik najpierw zostaje wprowadzony w tę tematykę, poczynając od savoir-vivre’u, by później poznać różnorodne zagadnienia związane z protokołem dyplomatycznym na arenie międzynaro- 
dowej. Szczególnie ten ostatni fragment wydaje się cenny, ponieważ traktuje o tematach nieoczywistych i nieczęsto poruszanych w pracach z zakresu komunikacji międzykulturowej.

We Wstępie recenzowanej pozycji Autorki informują, że powstała ona "z potrzeby dydaktyki”. To zamierzenie jest zauważalne na każdej stronie i należy stwierdzić, że zostało w pełni zrealizowane. Dzięki przystępnemu stylowi wypowiedzi, licznym przykładom i ciekawostkom, wytłuszczeniu głównych pojęć, a także podsumowaniom najistotniejszych informacji w formie tabel lektura jest przyjemna i bez wątpienia mogłaby stanowić element zajęć z zakresu komunikacji międzykulturowej. Podręcznikowy charakter opracowania jest jego niewątpliwym atutem. Dorota Glondys i Małgorzata Bednarczyk przyczyniły się do uzupełnienia dotkliwej luki na polskim rynku wydawniczym. Komunikacja międzykulturowa albo lepiej nie wychodź z domu to - obok opublikowanego w 2019 roku tomu Komunikacja interkulturowa. Wprowadzenie autorstwa Weroniki Wilczyńskiej, Jarosława Krajki i Macieja Mackiewicza oraz bardziej specjalistycznego opracowania Komunikacja niewerbalna. Płeć i kultura Urszuli Kusio i Ewy Głażewskiej - jedna z nielicznych wydanych w ostatnich latach publikacji, które mogłyby posłużyć jako podstawa nie tylko zajęć akademickich, lecz również szkoleń, warsztatów i prelekcji dla szerszego grona odbiorców mających do czynienia z różnorodnością kulturową na co dzień lub chcących samodzielnie zgłębiać ten temat. Po lekturze czytelnik nie ma wątpliwości co do tego, że zawarta w tytule groźba nie była jedynie zabiegiem retorycznym, lecz ma uzasadnienie w praktyce - podstawowa wiedza z zakresu różnorodności kulturowej przyda się w niemal każdej sferze życia, od relacji zawodowych, przez przyjacielskie, biznesowe i wiele innych. Recenzowana pozycja pozwala zaspokoić tę potrzebę z naddatkiem, a dociekliwego czytelnika z pewnością zachęci do dalszego eksplorowania podjętej w niej tematyki. 